\title{
Isolation, Identification and Extracellular Enzymatic Activity of Culturable Extremely Halophilic Archaea and Bacteria of IncheBoroun Wetland
}

\author{
Mehrnoosh Rasooli ${ }^{1, a}$, Mohammad Ali Amoozegar ${ }^{2,{ }^{*} \mathrm{~b}}$, \\ Abbas Akhavan Sepahy ${ }^{3, \mathrm{c}}$, Hamid Babavalian ${ }^{4,}$, , Hamid Tebyanian $^{5, \mathrm{e}}$ \\ ${ }^{1}$ Microorganisms Bank, Iranian Biological Resource Centre (IBRC), ACECR Tehran, Iran \\ ${ }^{2}$ Extremophiles Laboratory, Department of Microbiology, \\ School of Biology and Center of Excellence in Phylogeny of Living Organisms, College of Science, \\ University of Tehran, Tehran, Iran \\ ${ }^{3}$ Microbiology Department, Faculty of Biological Sciences, \\ Islamic Azad University North Tehran Branch, Tehran, Iran \\ ${ }^{4}$ Applied Virology Research Center, Baqiyatallah University of Medical Sciences, Tehran, Iran \\ ${ }^{5}$ Applied Biotechnology Research Center, Baqiyatallah University of Medical Sciences, \\ Tehran, Iran \\ arasooli@gmail.com, bamoozegar@ut.ac.ir, \\ cakhavansepahy@gmail.com, ${ }^{c}$.babavalian@yahoo.com, ${ }^{e}$ tebyan.hamid@yahoo.com \\ ${ }^{*}$ Corresponding author
}

Keywords: biodiversity, 16S rRNA gene, halophilic archaea

\begin{abstract}
Extremely halophilic diversity of IncheBroun wetland located in the north of Iran was investigated by using culture-dependent methods. Sampling was carried out in May and September 2014. In each sampling 4 distinct regions of wetland were analyzed by using complex media like MGM, JCM168, MH1 and an alkaliphilic medium containing $23 \%$ salts. After incubation at $40^{\circ} \mathrm{C}$, a total of 406 isolates and $2.1 \times 10^{6} \mathrm{CFU} / \mathrm{ml}$ were obtained in culture media. Among them 361 isolates were obtained from MGM and 39 isolates from JCM 168, 3 isolates from MH1 and 3 isolates from the alkaliphilic media. Initial morphological, biochemical and physiological tests were performed. Production of 4 hydrolytic enzymes by 45 selected strains was assayed qualitatively. A total of 38, 19 and 6 strains were able to produce lipase, DNase and amylase activity. Protease activity was not observed among strains. As total 45 strains were selected randomly and phylogenetic analysis of $16 \mathrm{~S}$ rRNA was performed for them. Among selected strains 40 isolated strians belonged to Haloarchaea and were belonged to the genera: Haloarcula $(30 \%)$, Halorubrum(27.5\%), Haloferax(17.5\%), Halobellus (10\%), Halogeometricum $(5.2 \%)$, Halobacterium(2.6\%), Halolamina(2.6\%), Halorhabdus (2.6\%) and Halostagnicola (2.6\%). Haloarcula and Halorubrum were the dominant populations. A total of 5 strains belonged to domain of Bacteria and were similar to members of Rhodovibrio (40\%), Pseudomonas (40\%) and Salicola $(20 \%)$.
\end{abstract}

\section{INTRODUCTION}

Hypersaline environments like solar salterns and natural saline lakes provide ecosystems with low diversity and high population densities. In such ecosystems, fundamental questions like biodiversity, natural selection, biogeography and evolution can be investigated more conveniently. The sediments of these waters often consist of diverse microbial populations that have not been investigated completely $[1,2]$. Different types of halophiles have confronted the problem of salinity stress (and other forms of stress) in different ways, so the study of microbial life in high salinity can be the answer to a vast majority of fundamental questions about the compatibility of microorganisms with their environments [3]. Hypersaline lakes often contain a large number of prokaryotes especially members of extremely halophilic archaea of the class Halobacteria. In such 
environments number of $10^{7}-10^{8} \mathrm{CFU} / \mathrm{ml}$ is not unusual. Members of Halobacteria are the most dominant microorganisms of hypersaline lakes, saltern crystallizer ponds, salt mines and also hypersaline alkaline lakes [4]. Halobacteria form a physiologically and phylogenetically distinct group of microorganisms and are characterized by their obligate halophile lifestyle and red coloration [5]. The development of red color in saline environments is a phenomenon which was observed thousand of years ago. Studies in the early $20^{\text {th }}$ century identified the cause and described several archaeal isolates [6].

Halophilic archaea can accumulate potassium ions intracellularly in order to balance the high salt content of saline environments. This ability differentiates this group from halophilic bacteria that produce compatible solutes like betaine and ectoine [7]. Due to the ability of survival in saline environments, halophilic microorganisms have great actual and potential capabilities in different fields of biotechnology. For instance, bacteriorhodopsins have some applications in holography, optical modulators, calculators and optical memories [8].

Production of biopolymers like biosurfactants and exopolysaccharides are considered as other applications of halophilic microorganisms [1, 2]. Iran has a great variety of hypersaline environments particularly hypersaline lakes. In recent years, great trends have been shown to researchers on hypersaline lakes of Iran which suggests the importance of these environments as important treasures of genetical and biological resources [4]. IncheBroun wetland as an instance of these unique ecosystems is an appropriate place for a survey of microbial diversity, particularly extremely halophilic microorganisms. IncheBroun wetland is located in the north of Iran (Golestan province). This wetland contains Iodine and an Iodine extraction plant is located in the vicinity of the wetland which drilled wells to a depth of 2500 meter and extracts waters containing iodine. During this process iodine, the effluent is released into the wetland. The eastern part of the wetland is affected by the effluents of the factory $(\mathrm{pH} \mathrm{1.5)}$ to the extent that the color of this part is changed to yellow to orange (color of iron) and the $\mathrm{pH}$ and composition of the wetland have been changed. Incheh Borun hypersaline wetland which was located in the north of Iran near the Turkmenistan border. This wetland is approximately 100 acres and has Mediterranean climate and also this wetland is remarkable because of salinity $(280 \mathrm{~g} / \mathrm{l})$ and variation of $\mathrm{pH}$ range (2.8 to 6.8). Sampling from IncheBroun wetland was conducted to evaluate changes in population during rainy and dry seasons. Similar investigations have been performed in other salt lakes of Iran, for instance, AranBidgol salt lake $[1,9]$.

\section{MATERIALS AND METHODS}

\section{Sample collection and physical-chemical determination}

Sampling from IncheBroun wetland (Golestan province, north of Iran) was carried out in May and September 2014 and in each sampling 4 distinct regions were analyzed. The exact geographical location of each site was recorded with GPS device. A total of 22 samples were taken from water, sediments and soils. The samples were taken aseptically and transferred to the lab within $24 \mathrm{~h}$. Temperature and $\mathrm{pH}$ were measured at each sampling site. Salinity and $\mathrm{pH}$ were also determined with a Multimeter. The soils and sediments of each sample were suspended in sterile $23 \% \mathrm{NaCl}$ solution and homogenized by stirring and vortexing then serially diluted up to $10^{-6} .100 \mu 1$ of selected dilutions were surface-plated on four different media including: 1-MGM 23\% (pH 7.2-7.3): $\mathrm{NaCl}, 184 ; \mathrm{MgCl}_{2} .6 \mathrm{H}_{2} \mathrm{O}, 23 ; \mathrm{MgSO}_{4} .7 \mathrm{H}_{2} \mathrm{O}, 26.8 ; \mathrm{KCl}, 5.3 ; \mathrm{CaCl}_{2}, 0.8$; peptone, 10; yeast extract, 2; distilled water, $1000 \mathrm{ml} .2-\mathrm{JCM} 168$ (pH 5.2): NaCl, 200; sodium glutamate, 1; trisodiumcitrate, 3; $\mathrm{MgSO}_{4} .7 \mathrm{H}_{2} \mathrm{O}, 20 ; \mathrm{KCl}, 2 ; \mathrm{FeCl}_{2} .4 \mathrm{H}_{2} \mathrm{O}, 0.0036 \mathrm{mg} ; \mathrm{MnCl}_{2} .4 \mathrm{H}_{2} \mathrm{O}, 0.00036$; yeast extracts, 5; Casamino acids, 5; agar, 20; distilled water, 1000ml.3-MH1 (pH 5.2): NaCl, 200; L-glutamic acid, 2; trisodiumcitrate, $2 ; \mathrm{K}_{2} \mathrm{SO}_{4}, 5 ; \mathrm{MgCl}_{2} .6 \mathrm{H}_{2} \mathrm{O}, 1 ; \mathrm{NH}_{4} \mathrm{Cl}, 1 ; \mathrm{FeSO}_{4} .7 \mathrm{H}_{2} \mathrm{O}, 0.004$; yeast extracts, 2; casamino acids, 5; agar, 20; distilled water, 1000ml.4-An alkaliphilic medium (pH 9.3): $\mathrm{NaCl}, 200$; $\mathrm{KH}_{2} \mathrm{PO}_{4}, 1 ; \mathrm{MgSO}_{4} .7 \mathrm{H}_{2} \mathrm{O}, 0.2 ; \mathrm{Na}_{2} \mathrm{CO}_{3}, 18$; casaminocacids, 5; agar, 20; distilled water, $1000 \mathrm{ml}$. Water samples were filtered through $0.22 \mu$ Millipore filter and each filter was placed on each of four media. All of the plates were incubated at $40{ }^{\circ} \mathrm{C}$ for 3 weeks. 


\section{Counts and isolation of the strains}

Counts were made in plates containing between 30 and 300 colonies. Selected colonies differing in shape, size and pigmentation which were isolated by retreating several times to obtain pure cultures. Gram staining was performed as described. Cell morphology and motility were examined microscopically in exponentially growing liquid cultures. Salt requirement and tolerance were examined in liquid media in which $\mathrm{NaCl}$ concentration was varied $(5,10,15,20,25$ and $30 \%)$. Antibiotic sensitivity was examined by spreading bacterial suspensions on plates containing the growth medium and applying antibiotic discs (nitrofurantoin,300mcg; novobiocin, 30mcg; chloramphenicol, $30 \mathrm{mcg}$; tetracycline, $30 \mathrm{mcg}$; erythromycin, $15 \mathrm{mcg}$; bacitracin, 10 units; penicillin $\mathrm{G}, 10$ units). The results were recorded as sensitive or resistant after 14 days of incubation at $40{ }^{\circ} \mathrm{C}$. Halophilic strains were placed into groups according to characteristics being investigated and 45 strains were randomly selected (22 strains from first sampling and 23 strains from second sampling).

\section{Determination of extracellular hydrolytic activity for selected strains}

Qualitative assay of 4 hydrolytic enzymes was performed using standard media. For each assay, $\mathrm{pH}$ was adjusted to 7.2-7.4 with Tris-base buffer. The 4 different media which were used for each assay are described below:

Determination of DNase activity was performed using $42 \mathrm{~g} / \mathrm{L}$ DNase test agar medium (Merck) supplemented with $23 \%$ total salt. After incubation in $40{ }^{\circ} \mathrm{C}$ for 21 days, production of clear halos around colonies after flooding with $1 \mathrm{M} \mathrm{HCl}$ was considered as a positive result [10]. Production of extracellular amylase activity was determined using MGM 23\% solid medium supplemented with $20 \mathrm{~g} \mathrm{l}^{-1}$ soluble starch. After incubation in $40{ }^{\circ} \mathrm{C}$ for 21 days, clear halos around colonies after flooding with $0.3 \%$ I2-0.6 \% KI solution indicated the hydrolysis of starch [11]. Determination of extracellular protease activity was performed using MGM 23\% solid media supplemented with 20 $\mathrm{g} / \mathrm{l}$ skim milk. Clear zones around growth area after 21 days incubation in $40^{\circ} \mathrm{C}$ was considered as a positive result [12]. Lipase activity was determined using MGM $23 \%$ solid media supplemented with $1 \%$ Tween 80 . After 21 days incubation production of opaque halos around the growth area was determined as a positive response [13]. DNA extraction, PCR amplification of 16S rRNA genes and sequencing Genomic DNA of archaeal strains were extracted using the Wanlam method and DNA of bacterial strains were extracted according to Marmur method with some modifications [14]. 16S rRNA genes were amplified in thermocycler with the following programme for archaea $94^{\circ} \mathrm{C}(3 \mathrm{~min})$, followed by 30 cycles of $94^{\circ} \mathrm{C}(15 \mathrm{~s}), 51^{\circ} \mathrm{C}(30 \mathrm{~s})$ and $72{ }^{\circ} \mathrm{C}(60 \mathrm{~s})$, with a final $7 \mathrm{~min}$ extension step of $72{ }^{\circ} \mathrm{C}$ and the following programme for bacteria: $94^{\circ} \mathrm{C}(2 \mathrm{~min})$, followed by 30 cycles of $94^{\circ} \mathrm{C}(60 \mathrm{~s}), 55^{\circ} \mathrm{C}(60 \mathrm{~s})$ and $72{ }^{\circ} \mathrm{C}(60 \mathrm{~s})$, with a final $7 \mathrm{~min}$ extension step of $72{ }^{\circ} \mathrm{C}$. A set of primers were used for archaeal and bacterial strains. 21F (5'-TTCCGGTTGATCCTGCCGGA-3') was used as archaeal-specific forward primer and 27F (5'-AGAGTTTGATCMTGGGTCAG-3') as bacterial specific forward primer and 1492R (5'- GGTTACCTTGTTACGACTT-3) as reverse primer. PCR amplifications were made using $50 \mu 1$ reaction mixtures containing PCR buffer (10X), $5 \mu \mathrm{l} ; \mathrm{MgCl}_{2}(5 \mathrm{mM}), 1.5 \mu \mathrm{l}$; dNTP mix $(10 \mathrm{mM}), 1 \mu \mathrm{l}$; Primers $(10 \mu \mathrm{M}$ each $), 2 \mu \mathrm{l}$; Taq DNA polymerase, $0.25 \mu \mathrm{l}$; Template DNA, 2-4 $\mu$; Sterilized distilled water, 34-38 $\mu \mathrm{l}$.

\section{Sequence analysis}

The sequences were identified by a similarity-based search using the EzTaxon server (http://eztaxon-e.ezbiocloud.net) [15]. Sequences were aligned using Clustal X2 [16]. Phylogenetic trees were constructed using neighbor-joining (NJ) and maximum likelihood criteria with MEGA version 5 [17]. The confidence level for the phylogenetic trees was assessed by bootstrapping with 1000 replicates. The sequence of the type strain Acetobacter cibinongensis strain Bf16 (JN004206.1) was used as an outgroup for bacterial phylogenetic tree and the sequence of Pyrococcus sp. Tc-2-70 (AB095146.1) was used as an outgroup for archaeal phylogenetic tree. 


\section{RESULTS}

\section{Sample characteristics}

The physicochemical properties of samples from IncheBroun wetland are presented in Table 1. In each sampling, 4 distinct regions of wetland were selected. The temperature of site 1 and 4 was same and more than other 2 sites. The salinity of each site in second sampling was 1.5 times higher than the first time. $\mathrm{Na}^{+}$and $\mathrm{Cl}^{-}$were identified as major ions in the samples so this wetland is considered as thalasso saline environments. In second sampling (dry season) the amount of $\mathrm{HCO}_{3}{ }^{-}$, $\mathrm{SO}_{4}{ }^{-}, \mathrm{Mg}^{2+}{ }^{2+} \mathrm{Fe}^{2+}$ and $\mathrm{K}^{+}$was much more than first samples. Despite the closure of site 1 and 4 , the amount of $\mathrm{Fe}^{2+}$ and $\mathrm{Na}^{+}$in site 4 was higher than site 1 (Table 2).

Table 1. The physicochemical properties of samples from IncheBroun wetland

\begin{tabular}{|c|c|c|c|c|c|c|c|c|c|}
\hline \hline \multirow{2}{*}{ Site } & \multirow{2}{*}{$\begin{array}{c}\text { Geographical } \\
\text { coordinates }\end{array}$} & $\begin{array}{c}\text { Mud } \\
\text { and } \\
\text { sludge }\end{array}$ & soil & salt & water & $\begin{array}{c}\text { Salinity } \\
\text { (may2014) }\end{array}$ & $\begin{array}{c}\text { Salinity } \\
\text { (September } \\
2014) 0\end{array}$ & $\begin{array}{c}\text { Average } \\
\text { temperature }\end{array}$ & $\mathrm{pH}$ \\
\hline 1 & $\begin{array}{c}\mathrm{N} 37^{\circ}, 13,438 \\
\mathrm{E}, 054,30,224\end{array}$ & 22 & 7 & 0 & 2 & 177 & 286.4 & 33 & 4.3 \\
\hline 2 & $\begin{array}{c}\mathrm{N} 37^{\circ}, 13,932 \\
\mathrm{E}, 054,30,081\end{array}$ & 3 & 0 & 0 & 0 & 176.7 & 287 & 31.8 & 5.2 \\
\hline 3 & $\begin{array}{c}\mathrm{N} 37^{\circ}, 13,829 \\
\mathrm{E}, 054,30,307\end{array}$ & 0 & 0 & 2 & 1 & 168 & 283.6 & 30 & 5.2 \\
\hline 4 & $\begin{array}{c}\mathrm{N} 37^{\circ}, 13,517 \\
\mathrm{E}, 059,30,657\end{array}$ & 4 & 1 & 0 & 2 & 159.8 & 232.6 & 33 & 6.4 \\
\hline
\end{tabular}

Table 2. Chemical composition of Brine samples

\begin{tabular}{ccc}
\hline Parameter & $\begin{array}{c}\text { Ion concentration (mg/l) in } \\
\text { (May, 2014) }\end{array}$ & $\begin{array}{c}\text { Ion concentration (mg/l) in } \\
\text { (September, 2014) }\end{array}$ \\
\hline $\mathrm{CO}_{3}{ }^{2-}$ & 0 & 0 \\
$\mathrm{HCO}_{3}{ }^{-}$ & 24.4 & 762.5 \\
$\mathrm{Cl}^{-}$ & 134748 & 145386 \\
$\mathrm{SO}_{4}^{2-}$ & 1444.7 & 7824.1 \\
$\mathrm{Ca}^{2+}$ & 41 & 11068 \\
$\mathrm{Mg}^{2+}$ & 40.4 & 7054.25 \\
$\mathrm{Na}^{+}$ & 56120 & 60774.5 \\
$\mathrm{Fe}^{2+}$ & 0.16 & 96.31 \\
$\mathrm{Mn}^{+}$ & 0.05 & 2.6 \\
$\mathrm{Cu}^{2+}$ & 0.015 & 0.064 \\
$\mathrm{Ni}^{+}$ & 3.43 & 0.1 \\
$\mathrm{Zn}^{2+}$ & $\mathrm{ND}$ & 0.16 \\
$\mathrm{~K}^{+}$ & 27.6 & 153.81 \\
\hline
\end{tabular}

\section{Diversity of microorganisms from IncheBroun wetland}

Viable counts obtained from MGM medium was ranged $2.1 \times 10^{6} \mathrm{CFU} / \mathrm{ml}$. From samples collected from Brines, sediments, waters and muds, a total of 406 isolates were obtained. In the first sampling, 229 isolates were obtained: 205 isolates from MGM, 2 from MH1, 21 from JCM 168 and 1 from the alkaliphilic medium. In the second sampling, 177 isolates were obtained: 156 isolates from MGM. 18 from JCM 168, 1 from MH1 and 2 from the alkaliphilic medium. The isolates obtained from acidophilic and alkaliphilic media were cultured on MGM medium and all of the isolates could grow on MGM with neutral $\mathrm{pH}$. Most isolates were obtained from site 1 and the least were obtained from site 4. 
Colonies ranged from red to white. Microscopy and gram staining results showed that from 406 isolates 33 strains were rods and 373 strains had irregular pleomorphic morphology. Gram reaction for 402 strains was negative and for 4 strains was positive and the results of gram staining reaction were confirmed by $\mathrm{KOH} 3 \%$ test. Oxidase and catalase tests were performed for all of the strains. The catalase test was positive for all of the strains but in some of them, the results were weakly positive. The oxidase reaction was negative for 98 strains and positive for the rest. Antibiotic susceptibility test was performed for 130 strains with Penicillin G (10 units), chloramphenicol (30 $\mathrm{mcg})$, erythromycin $(15 \mathrm{mcg})$, nitrofurantoin $(300 \mathrm{mcg})$, Tetracycline $(30 \mathrm{mcg})$, novobiocin $(30$ $\mathrm{mcg}$ ), bacitracin (10 units). In 101 strains sensitivity to nitrofurantoin, novobiocin and bacitracin and resistance to other antibiotics was observed.

\section{Extracellular hydrolytic activity of selected strains}

Production of 4 hydrolytic enzymes by 45 selected strains was assayed qualitatively. A total of 38, 19 and 6 strains were able to produce lipase, DNase and amylase activity. Protease activity was not observed among strains and lipase and DNase activity were the most common activities among the selected strains.

\section{Phylogenetic identification of selected strains}

A subset of 45 strains (22 from first sampling and 23 from second sampling) was randomly selected and analyzed. Specific primers were used for the hypervariable region of the 16S rRNA gene of Archaea and Bacteria and by sequencing the PCR products a preliminary phylogeny of the strains was determined.The results of molecular identification of selected strains are represented in Table 3. All of the archaeal isolates belonged to Halobactriacaeaand they were phylogenetically similar to members of Haloarcula (30\%), Halorubrum (27.5\%), Haloferax (17.5\%), Halobellus (10\%), Halogeometricum (5.2\%), Halobacterium (2.6\%),Halolamina (2.6\%), Halorhabdus (2.6\%) and Halostagnicola (2.6\%). Bacterial strains were phylogenetically similar to members of Rhodovibrio (40\%), Pseudomonas (40\%) and Salicola (20\%). Most of the strains belonged toHaloarcula, Halorubrum and Haloferax.Trees reconstructed with neighbor-joining and maximum likelihood methods showed similar results (Figure 1 and 2).

Table 3. Affiliation of the 16S rRNA gene sequences on the basis of pairwise comparison by the EzTaxon server (http://eztaxon-e.ezbiocloud.net).

\begin{tabular}{|c|c|c|c|c|}
\hline Strain & $\begin{array}{c}\text { Isolation } \\
\text { site }\end{array}$ & Sample & \%Identity & Taxon (type strain) \\
\hline A6 & S1 & Sludge & 100 & Haloferax prahovense TL6 $^{\mathrm{T}}(\mathrm{AB} 258305)$ \\
\hline $\mathbf{A 1 2 A}$ & S1 & Sludge & 99.5 & Haloferax prahovense $\mathrm{TL}^{\mathrm{T}}$ (AB258305) \\
\hline $\mathrm{AC2}$ & S1 & Mud & 98.4 & Haloarcula japonica $\mathrm{JCM} 785^{\mathrm{T}}$ (AB355986) \\
\hline AC6 & S1 & Mud & 94.7 & Halobellus clavatus TNN18 ${ }^{\mathrm{T}}$ (GQ282620) \\
\hline AC7 & S1 & Mud & 99.4 & Halogeometricum rufum RO1-4 ${ }^{\mathrm{T}}$ (EU887286) \\
\hline AD1 & S1 & Salt & 99.2 & Halorubrum chaoviator Halo-G ${ }^{\mathrm{T}}$ (AM048786) \\
\hline AD3 & S1 & Salt & 99.3 & Halorubrum chaoviator Halo-G ${ }^{\mathrm{T}}$ (AM048786) \\
\hline AD7 & S1 & Salt & 100 & Halorubrum chaoviator Halo-G ${ }^{\mathrm{T}}$ (AM048786) \\
\hline AM1 & S1 & Mud & 98.7 & Haloarcula argentinensisarg- $1^{\mathrm{T}}$ (D50849) \\
\hline AM2 & $\mathrm{S} 1$ & Mud & 98.3 & Haloarcula japonica JCM7785 (AB355986) \\
\hline AM5 & S1 & Mud & 98.1 & Haloarcula japonica JCM7785 ${ }^{\mathrm{T}}$ (AB355986) \\
\hline AM14 & S1 & Mud & 98.2 & Halolamin apelagica $\mathrm{TBN} 21^{\mathrm{T}}(\mathrm{GU} 208826)$ \\
\hline AM17 & $\mathrm{S} 1$ & Mud & 97.7 & Haloarculam arismortui ATCC $43049^{\mathrm{T}}$ (AY596297) \\
\hline AO2 & S1 & Sludge & 99.8 & Haloferax alexandrines $\mathrm{TM}^{\mathrm{T}}$ (AB037474) \\
\hline AO7 & S1 & Sludge & 93.9 & Halobellus clavatus TNN18 ${ }^{\mathrm{T}}$ (GQ282620) \\
\hline
\end{tabular}




\begin{tabular}{|c|c|c|c|c|}
\hline B1A & S1 & Sludge & 98.8 & Haloarcula quadrata $801030 / 1^{\mathrm{T}}(\mathrm{AB} 010964)$ \\
\hline B2 & S1 & Sludge & 99.5 & Haloarcula hispanica ATCC $33960^{\mathrm{T}}(\mathrm{CP} 002921)$ \\
\hline B4 & $\mathrm{S} 1$ & Sludge & 99.2 & Halorubrum chaoviator Halo-G ${ }^{\mathrm{T}}$ (AM048786) \\
\hline B5 & $\mathrm{S} 1$ & Sludge & 99.8 & Psuedomonas halophila DSM3050 (AB021383) \\
\hline B8 & $\mathrm{S} 1$ & Sludge & 100 & Halorhabdus tiamatea SARL4B $^{\mathrm{T}}$ (EF127229) \\
\hline B16 & $\mathrm{S} 1$ & Sludge & 98.6 & Halorubrum chaoviator Halo-G ${ }^{\mathrm{T}}$ (AM048786) \\
\hline CW8 & S3 & Brine & 100 & Halorubrum chaoviator Halo-G ${ }^{\mathrm{T}}$ (AM048786) \\
\hline Ct1 & S3 & Salt & 100 & Halorubrum chaoviator Halo-G ${ }^{\mathrm{T}}$ (AM048786) \\
\hline Ct4 & $\mathrm{S} 3$ & Salt & 99.8 & Halorubrum chaoviator Halo-G ${ }^{\mathrm{T}}$ (AM048786) \\
\hline D19 & $\mathrm{S} 2$ & Sludge & 99.2 & Halorubrum chaoviator Halo-G ${ }^{\mathrm{T}}$ (AM048786) \\
\hline DA5 & S4 & Mud & 100 & Haloferax prahovense TL6 ${ }^{\mathrm{T}}$ (AB258308) \\
\hline DA7 & $\mathrm{S} 4$ & Mud & 97.7 & Haloarcula japonica JCM7785 (AB355986) \\
\hline DB3 & S4 & Mud & 93.6 & Halobellus clavatus TNN18 ${ }^{\mathrm{T}}$ (GQ282620) \\
\hline DM1 & S4 & Mud & 93.8 & Halobellus clavatus $\mathrm{TNN} 18^{\mathrm{T}}$ (GQ282620) \\
\hline DS16 & S4 & Soil & 98.7 & Haloarcula amylolytica $\mathrm{BD}-3^{\mathrm{T}}$ (DQ826513) \\
\hline DW4 & $\mathrm{S} 4$ & Brine & 99.5 & Halogeometricum rufum RO1-4 ${ }^{\mathrm{T}}$ (EU887286) \\
\hline E4B & $\mathrm{S} 2$ & Sludge & 99.6 & Halobacterium salinarum NRC-1 (AE004437) \\
\hline F4 & $\mathrm{S} 2$ & Sludge & 98.9 & Rhodovibrio sodomensis DSM $9895^{\mathrm{T}}$ (FR733704) \\
\hline H7 & $\mathrm{S} 1$ & Sludge & 100 & Haloferax prahovense TL6 ${ }^{\mathrm{T}}$ (AB258308) \\
\hline I1 & S1 & Sludge & 99.3 & Haloarcul aquadrata 801030/1 ${ }^{\mathrm{T}}(\mathrm{AB} 010964)$ \\
\hline $\mathbf{I 3}$ & $\mathrm{S} 1$ & Sludge & 98.6 & Haloarcula argentinensisarg- $1^{\mathrm{T}}$ (D50849) \\
\hline $\mathbf{I 5}$ & $\mathrm{S} 1$ & Sludge & 98.5 & Psuedomonas halophile DSM3050 (AB021383) \\
\hline I6A & $\mathrm{S} 1$ & Sludge & 98.5 & Haloarcul asalaria HST01-2R $\mathrm{R}^{\mathrm{T}}$ (FJ429317) \\
\hline I8 & $\mathrm{S} 1$ & Sludge & 99.1 & Rhodovibrio sodomensis DSM 9895 (FR733704) \\
\hline $\mathbf{J} 2$ & $\mathrm{~S} 1$ & Soil & 96.5 & Halorubrum lipolyticum 9-3 ${ }^{\mathrm{T}}$ (DQ355814) \\
\hline $\mathbf{J} 7$ & $\mathrm{~S} 1$ & Soil & 98.4 & Halostagnicola larsenii XH-48 ${ }^{\mathrm{T}}$ (AM117571) \\
\hline $\mathbf{0 5}$ & $\mathrm{S} 1$ & Brine & 99.3 & Haloferax prahovense TL6 ${ }^{\mathrm{T}}$ (AB258305) \\
\hline O6B & $\mathrm{S} 1$ & Brine & 99.6 & Salicola salis $\mathrm{B} 2^{\mathrm{T}}$ (DQ129689) \\
\hline $\mathbf{R 8}$ & $\mathrm{S} 4$ & Brine & 98.7 & Halorubrum chaoviator Halo-G ${ }^{\mathrm{T}}$ (AM048786) \\
\hline S1A1 & $\mathrm{S} 1$ & Sludge & 99.5 & Haloferax prahovense TL6 ${ }^{\mathrm{T}}$ (AB258305) \\
\hline
\end{tabular}




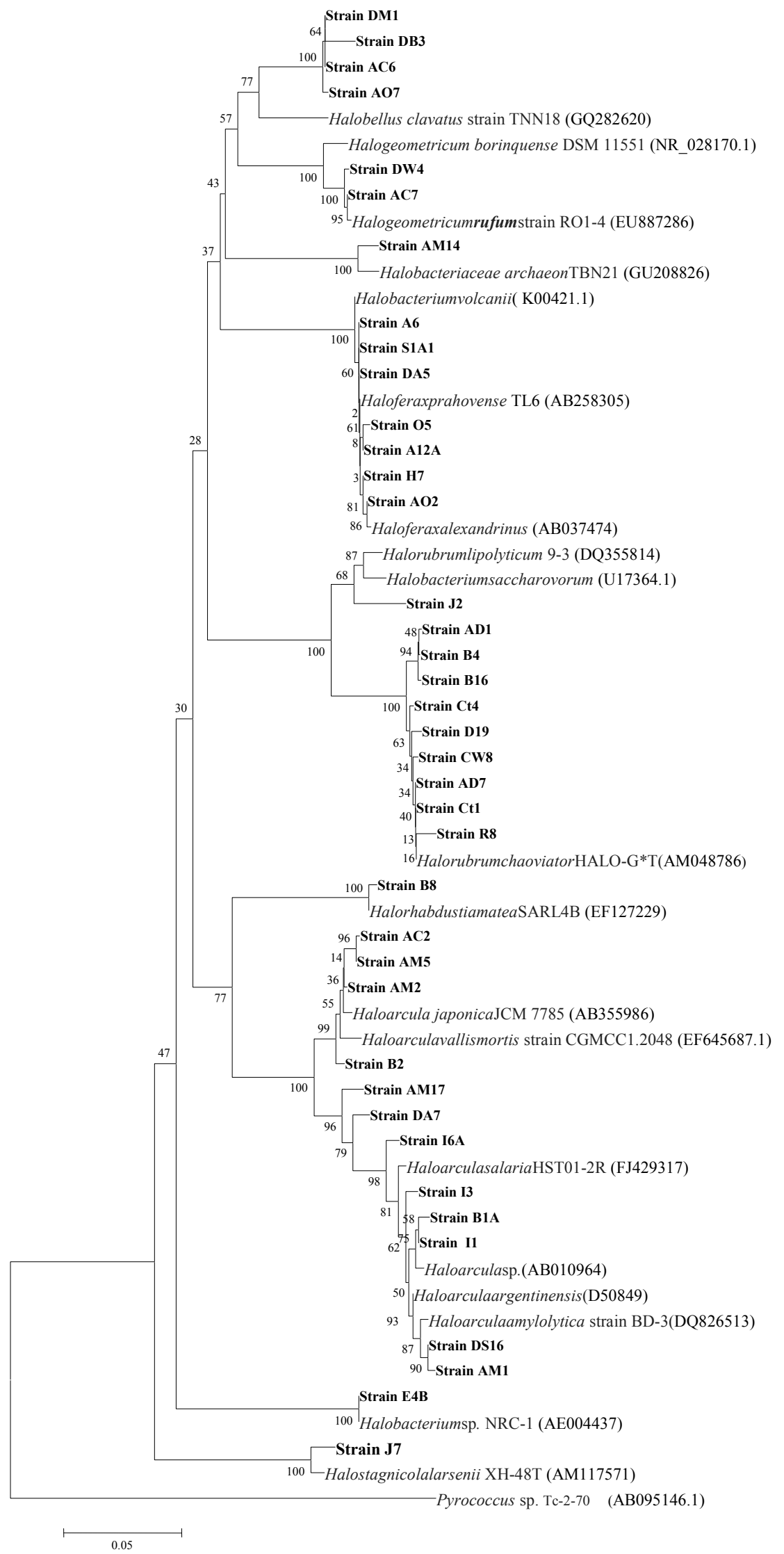

Figure 1. Phylogenetic tree for selected strains belonged to Archaea constructed with neighbor-joining methods. 


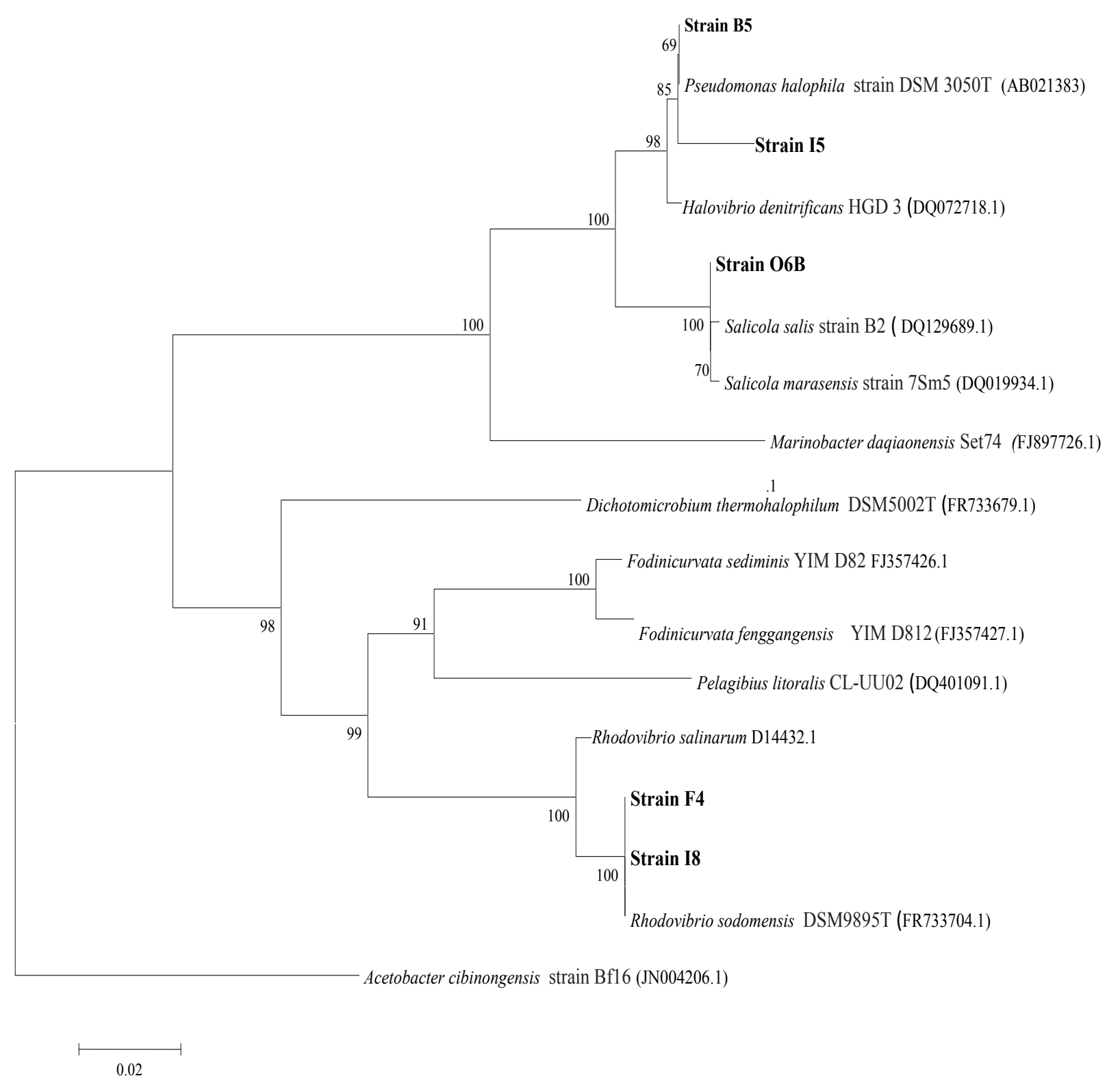

Figure 2. Phylogenetic tree for selected strains belonged to Bacteria constructed with neighborjoining methods.

\section{DISCUSSION}

In this survey diversity of halophilic archaea of Inche-Broun wetland was investigated for the first time. The low $\mathrm{pH}$ of this wetland makes it distinct from other hypersaline environments of Iran like Howz-Soltan and Aran-Bidgol lakes with high salinity and neutral $\mathrm{pH}$ and Gomishan wetland with low salinity and high $\mathrm{pH}$. In comparison with Tuz lake in Turkey [18] and Marras lake in Peru [19]. The amount of $\mathrm{Mg}^{2+}$ ion of this wetland was lower and also in comparison with other hypersaline lakes of Iran, the amount of $\mathrm{Mg}^{2+}$ in Urmia lake and Aran-Bidgol lake was in order 3.5 and 1.5 times higher than IncheBroun wetland. The salinity of IncheBroun wetland was lower than AranBidgol salt lake with salinity near saturation, but in second sampling, it was higher than the west coast of Urmialake.

The salinity of each sampling site in second sampling was increased 1.5 times. As a resulting possibility of isolation of moderately halophilic bacteria was higher in first sampling. The highest amount of $\mathrm{Fe}^{2+}$ ion was in 4 sites and the least isolation was performed from this site. Due to the close distance to the iodine extraction plant, the fourth region had high amounts of sulfate ions. So, isolation of sulfate-reducing bacteria from this region was more likely. In this survey in order to the 
maximum isolation of extremely halophilic microorganisms, a variety of media were used and efficiency of MGM was evaluated higher than other media. The usage of media like JCM 168 and MH1 in similar surveys led to the isolation of microorganisms which were acidophilic or were able to have optimum growth at low $\mathrm{pH}$ [20]. Due to the acidic $\mathrm{pH}$ of some regions of the wetland, 2 appropriate media for isolation of acidophilic microorganisms were used. The obtained strains were cultured in MGM with pH 7.2 in order to investigate the ability of growth in neutral $\mathrm{pH}$. All of them were able to grow in neutral $\mathrm{pH}$, so these strains cannot be considered as true acidophilic microorganisms.

The usage of serial dilution methods along with prolonged incubation resulted in the maximum isolation of halophilic microorganisms. The obtained colonies were often red or orange pigmented with some exception of colorless, white and pink colonies that were observed in some of the media. The average colony counts of extremely halophilic microorganisms were $2.1 \times 10^{6} \mathrm{cfu} / \mathrm{ml}$. Undoubtedly, the diversity of described halophilic archaea of this survey represents only a small fraction of the true diversity of IncheBroun wetland. In Brines, especially red brings $10^{7}-10^{8}$ colonies of archaea are expected, but due to the lower salinity of this wetland in contrast with other wetlands or salt lakes, the number of recovered colonies in this was lower. Also, the usage of media containing high amounts of salts and nutrients acts selectively. The more robust recovery is possible with the usage of media containing low nutrients and prolonged incubation time [21]. Susceptibility to antibiotics and other antimicrobial substances is a criterion which is often used in taxonomical studies in which strains are described or compared. Most members of Halobacteriacaeaare generally resistant to specific antibiotics for bacteria like penicillin, ampicillin, kanamycin, neomycin, polymixin and streptomycin [22]. Novobiocin is a DNA gyrase inhibitor and in sensitive bacteria and archaea acts in the same place [23]. Bacitracin inhibits intercalation of high molecular weight saccharides in glycoproteins of cell walls of halophilic archaea, it also inhibits biosynthesis of lipids in these organisms [24]. Sensitivity to nitrofurantoin is also observed in halophilic archaea [25]. The results of our susceptibility tests are in accordance with these data. Members of Halobacteria sensitive to some other antibiotics and antimicrobial substances that from this group anisomycin can be mentioned as an inhibitor of protein synthesis in eukaryotic ribosomes so use of this antibiotic is suggested for differentiation of bacteria from archaea [26].

Among the strains belonged to archaea most of them were similar to members of Haloarcula and Halorubrum(in order 30 and 27.5 percents of the isolates). Results of other surveys performed in other hypersaline regions of the world shows that: members of Halorubrum and Haloarculaare the main groups of isolates from Tuz salt lake in Turkey [18], members of Haloarculaconstitue 50 percent of the isolates of Maras lake in Peru[18], in solar slatterns of Australia more than 70 percent of the isolates belonged to genus Halorubrum and in Ayakekumu salt lake in China 47 percent of isolates belonged to genus Halorubrum and 24 percents were belonged to Natrinema [27]. In surveys performed in Aran-Bigol salt lake in Iran the archaeal isolates were similar to members of Halorubrum, Haloarcula, Natrinema, Halogeometricum, Natronomonas, Halobacterium, Halovivax, Halolamina and Halorientalis [9]. Also in surveys performed in west coasts of Urmia salt lake, the investigated isolates were similar to members of Halorubrum, Haloarcula, Natrinema, Natronococcus, Natronomonas, Halobacterium, Halovivax, Halosimplex, Haloterrigenaand Halobiforma, Halomicrobium and Haloplagius [2]. Unlike Inche-Broun wetland, most of the isolates of Urmia and Aran-Bidgol salt lakes were similar to a member of Halorubrum and Haloarcula (in order) and no isolate similar to genus Haloferaxhas been obtained from these salt lakes. In this survey 7 strains $(17.5 \%$ of the strains) similar to members of Haloferax had been isolated and despite the low amount of $\mathrm{Na}^{+}$and $\mathrm{Mg}^{2+}$ ions in region 1, 6 of them had been isolated from this region. Investigations have shown that member of this genus have the lowest amount of optimal salinity among halophilic archaea and require minimum salinity to maintain their cellular structure [28]. 
Inoculation of brines on plates containing high concentrations of salts and enriched with complex nutritious results in isolation of strains from Halorubrum, Haloarcula and Haloferax. This can be because the ability exists to grow in this condition and it is not because of the abundance of them in environments [29]. According to the low $\mathrm{pH}$ of this wetland in comparison with Aran-Bidgol and Urmia lakes, inability to isolate haloalkaliphilic strains like a member of the genus Natronomonas and Natronococcus are not unexpected.

Members of genus Halobacterium are the dominant group of the halo archaeal populations in salt lakes [26]. In this study only one strain similar to members of this genus was obtained. High salinities and organic compounds in isolation media can act as a selective factor to isolate members of this genus. Although the microbial diversity of hypersaline environments is of great interest during last decade, only a few studies are conducted that concern the production of extracellular enzymes from halo archaea as predominant microorganisms of this extreme environment [30]. The ability to produce 4 hydrolytic enzymes was assayed qualitatively among selected strains of IncheBroun wetland. Lipase and DNAse were the most common hydrolytic activities among selected strains by $82 \%$ and $42 \%$ abundance respectively. No proteinase activity was observed. Hydrolytic activity was more observed in strains similar to members of Halorubrum, Haloarcula and Haloferax. Amylase activity was only observed in strains belonged to Haloarcula. No hydrolytic activity was observed in strains similar to members of Halobellus. Combined hydrolytic activity was observed in some of the strains. 3 strains were able to present 3 hydrolytic activity, 20 strains were able to present 2 hydrolytic activity, 15 strains were able to present one hydrolytic activity and 7 had no hydrolytic activity. The most enzyme producers belonged to Halorubrum. The phylogenetic analysis revealed that Halorubrum and Haloarcula are two dominant halo archaeal genera that showed high rate enzyme production [31].

Eleviet al. (2004) studied the production of amylase, protease and lipase in halo archaea. They reported a high rate of amylase activity but neither protease nor lipase activity was observed [18]. Among bacterial strains only lipase activity was observed in strains similar to members of Psuedomonas and Salicola. Lipase and DNase activity were observed in strains belonged to Rhodovibrio. Due to the fact that aim of this research was focused on the isolation of extremely halophilic microorganisms, appropriate media for isolation of moderately halophilic microorganisms and halotolerant microorganisms were not selected, so as a result, the proper isolation of members of these groups was not possible. Despite this, most of the bacterial isolates of this study were similar to members of genus Rhodovibriowhich are moderately halophilic bacteria and were first isolated from sediments and waters of the Dead sea and are members of Alphaproteobacteria. Strains similar to members of genus Salicola and Pseudomonas are other bacterial isolates of this study. Salicola is a non-pigmented and extremely halophilic bacteria which was first isolated from shallow salt lakes of Algeria [32]. Pseudomonas halophiles a moderately halophilic bacteria and was first isolated from Great Salt Lake in the USA [33].

\section{CONCLUSION}

In general, it can be concluded that isolation and identification of microorganisms as treasures of biological resources is of particular importance and knowledge of biodiversity provides a powerful tool to achieve this important goal. In this study diversity of extremely halophilic archaea of IncheBroun wetland was investigated for the first time and given the limited number of identified genera of halophilic archaea, the result of this study reflects the relatively high diversity of extremely halophilic archaea in this wetland. 


\section{REFERENCES}

[1]. H. Babavalian, et al., Isolation and identification of moderately halophilic bacteria producing hydrolytic enzymes from the largest hypersaline playa in Iran, Microbiology. 82(4) (2013) 466-474.

[2]. H. Babavalian, et al., Comparison of bacterial biodiversity and enzyme production in three hypersaline lakes; Urmia, Howz-Soltan and Aran-Bidgol, Indian journal of microbiology. 54(4) (2014) 444-449.

[3]. Y. Ma, et al., Halophiles 2010: life in saline environments, Applied and environmental microbiology. 76(21) (2010) 6971-6981.

[4]. M. Rasooli, M. Ali Amoozegar and A.A. Sepahy, Isolation and identification of culturable extremely halophilic archaea of Inche-Boroun wetland, Taxonomy \& Biosystematics. 5(16) (2013).

[5]. A. Oren, The order halobacteriales, in The prokaryotes. 2006, Springer. p. 113-164.

[6]. A. Oren, A. Ventosa and W.D. Grant, Proposed minimal standards for description of new taxa in the order Halobacteriales, International Journal of Systematic and Evolutionary Microbiology. 47(1) (1997) 233-238.

[7]. N. Empadinhas and M.S.d. Costa, Diversity and biosynthesis of compatible solutes in hyper/thermophiles, (2006).

[8]. R. Margesin and F. Schinner, Potential of halotolerant and halophilic microorganisms for biotechnology, Extremophiles. 5(2) (2001) 73-83.

[9]. A. Makhdoumi-Kakhki, et al., Prokaryotic diversity in Aran-Bidgol salt lake, the largest hypersaline playa in Iran, Microbes and Environments. 27(1) (2012) 87-93.

[10]. H. Onishi, et al., Halophilic nuclease of a moderately halophilic Bacillus sp.: production, purification, and characterization, Applied and environmental microbiology. 45(1) (1983) 24-30.

[11]. M.A. Amoozegar, F. Malekzadeh and K.A. Malik, Production of amylase by newly isolated moderate halophile, Halobacillus sp. strain MA-2, Journal of microbiological methods. 52(3) (2003) 353-359.

[12]. M.A. Amoozegar, et al., Salinivibrio proteolyticus sp. nov., a moderately halophilic and proteolytic species from a hypersaline lake in Iran, International journal of systematic and evolutionary microbiology. 58(5) (2008) 1159-1163.

[13]. M.A. Amoozegar, et al., Production of an extracellular thermohalophilic lipase from a moderately halophilic bacterium, Salinivibrio sp. strain SA-2, Journal of basic microbiology. 48(3) (2008) 160-167.

[14]. J. Marmur, A procedure for the isolation of deoxyribonucleic acid from micro-organisms, Journal of Molecular Biology. 3(2) (1961) 208-IN1.

[15]. O.-S. Kim, et al., Introducing EzTaxon-e: a prokaryotic 16S rRNA gene sequence database with phylotypes that represent uncultured species, International journal of systematic and evolutionary microbiology. 62(3) (2012) 716-721.

[16]. J.D. Thompson, et al., The CLUSTAL_X windows interface: flexible strategies for multiple sequence alignment aided by quality analysis tools, Nucleic acids research. 25(24) (1997) 4876-4882.

[17]. S. Kumar, et al., MEGA: a biologist-centric software for evolutionary analysis of DNA and protein sequences, Briefings in bioinformatics. 9(4) (2008) 299-306.

[18]. R. Elevi, et al., Characterization of extremely halophilic Archaea isolated from the Ayvalik Saltern, Turkey, World Journal of Microbiology and Biotechnology. 20(7) (2004) 719-725.

[19]. L. Maturrano, et al., Microbial diversity in Maras salterns, a hypersaline environment in the Peruvian Andes, Applied and Environmental Microbiology. 72(6) (2006) 3887-3895.

[20]. H. Minegishi, et al., Acidophilic haloarchaeal strains are isolated from various solar salts, Saline systems. 4(1) (2008) 1. 
[21]. K. Mani, B.B. Salgaonkar and J.M. Braganca, Culturable halophilic archaea at the initial and crystallization stages of salt production in a natural solar saltern of Goa, India, Aquatic biosystems. 8(1) (2012) 1.

[22]. R. Ghosh, et al., Antibiotic resistance profile of halophilic microorganisms isolated from tannery effluent, Indian journal of biotechnology. 9(1) (2010) 80-86.

[23]. M.L. Holmes and M.L. Dyall-Smith, Mutations in DNA gyrase result in novobiocin resistance in halophilic archaebacteria, Journal of bacteriology. 173(2) (1991) 642-648.

[24]. N. Moldoveanu and M. Kates, Effect of bacitracin on growth and phospholipid, glycolipid and bacterioruberin biosynthesis in Halobacterium cutirubrum, Microbiology. 135(9) (1989) 2503-2508.

[25]. F.F. Hezayen, et al., Characterization of a novel halophilic archaeon, Halobiforma haloterrestris gen. nov., sp. nov., and transfer of Natronobacterium nitratireducens to Halobiforma nitratireducens comb. nov, International journal of systematic and evolutionary microbiology. 52(6) (2002) 2271-2280.

[26]. M. Dworkin, et al., The Prokaryotes: Vol. 7: proteobacteria: Delta and Epsilon subclasses. deeply rooting bacteria. 2006: Springer Science \& Business Media.

[27]. X. Xu, et al., Culturable halophilic archaeal diversity of Ayakekumu salt lake located in Xinjiang, China, Acta Ecologica Sinica. 27(8) (2007) 3119-3123.

[28]. S.E. D'Souza, W. Altekar and S.F. D'Souza, Adaptive response of Haloferax mediterranei to low concentrations of $\mathrm{NaCl}(<20 \%)$ in the growth medium, Archives of microbiology. 168(1) (1997) 68-71.

[29]. R.E. Bardavid, P. Khristo and A. Oren, Interrelationships between Dunaliella and halophilic prokaryotes in saltern crystallizer ponds, Extremophiles. 12(1) (2008) 5-14.

[30]. C. Lizama, et al., Taxonomic study of extreme halophilic archaea isolated from the "Salar de Atacama", Chile, Systematic and applied microbiology. 24(3) (2001) 464-474.

[31]. A.M. Kakhki, M.A. Amoozegar and E.M. Khaledi, Diversity of hydrolytic enzymes in haloarchaeal strains isolated from salt lake, International Journal of Environmental Science \& Technology. 8(4) (2011) 705-714.

[32]. K. Kharroub, et al., Halorubrum ezzemoulense sp. nov., a halophilic archaeon isolated from Ezzemoul sabkha, Algeria, International journal of systematic and evolutionary microbiology. 56(7) (2006) 1583-1588.

[33]. C. Fendrich, Halovibrio variabilis gen. nov. sp. nov., Pseudomonas halophila sp. nov. and a new halophilic aerobic coccoid Eubacterium from Great Salt Lake, Utah, USA, Systematic and Applied Microbiology. 11(1) (1988) 36-43. 